\begin{abstract}
The porbeagle (Lamna nasus) is a slow-growing, late-maturing, long-lived pelagic shark that inhabits cold temperate waters. Previous research based on specimens collected from the western North Atlantic Ocean has indicated that this lamnid shark has an annual reproductive cycle. However, the results of a recent evaluation of reproductive tracts from a geographically segregated group of porbeagles within the western North Atlantic Ocean indicate the presence of females in a resting stage of maturity. The observation of a resting stage has implications not only in the reproductive cycle, biennial versus annual, of this species but also in the lifetime productivity. This finding indicates that this shark follows the typical lamnid resting period between pregnancies, a period that would decrease the lifetime output of young sharks and their resilience to direct and indirect fishing pressure.
\end{abstract}

Manuscript submitted 9 October 2018. Manuscript accepted 8 March 2019. Fish. Bull. 117:70-77 (2019). Online publication date: 25 March 2019. doi: 10.7755/FB.117.1-2.8

The views and opinions expressed or implied in this article are those of the author (or authors) and do not necessarily reflect the position of the National Marine Fisheries Service, NOAA.

\title{
Presence of a resting population of female porbeagles (Lamna nasus), indicating a biennial reproductive cycle, in the western North Atlantic Ocean
}

\author{
Lisa J. Natanson (contact author)' ${ }^{1}$ \\ Bethany M. Deacy ${ }^{2}$ \\ Warren Joyce ${ }^{3}$ \\ James Sulikowski ${ }^{4}$ \\ Email address for contact author: lisa.natanson@noaa.gov \\ 1 Northeast Fisheries Science Center \\ National Marine Fisheries Service, NOAA \\ 28 Tarzwell Drive \\ Narragansett, Rhode Island 02882 \\ 2 Riverside Technologies, Inc. \\ for National Marine Fisheries Service, NOAA \\ 3500 Delwood Beach Road \\ Panama City, Florida 32408 \\ 3 Population Ecology Division \\ Bedford Institute of Oceanography \\ P.O. Box 1006 \\ Dartmouth, Nova Scotia, Canada, B2Y 4A2 \\ ${ }^{4}$ Department of Marine Sciences \\ University of New England \\ 11 Hills Beach Road \\ Biddeford, Maine 04005
}

The porbeagle (Lamna nasus), a pelagic shark in the family Lamnidae, inhabits the cold temperate waters of the North and South Atlantic, South Pacific, and southern Indian Oceans as well as the subantarctic region of the Southern Ocean (Castro, 2011). In the western North Atlantic Ocean, the porbeagle ranges from the Grand Banks of Newfoundland, Canada, to the Gulf of Maine and rarely south to New Jersey (Castro, 2011). Seasonal abundance is related to north-south migrations and reproductive stage (Aasen ${ }^{1}$; Aasen, 1963; Campana et al., 2008; Campana et al., 2010a). Reproductive migrations are indicated by the occurrence of both mature males and mature females off the Grand Banks of Newfoundland in fall for mating (Jensen et al., 2002). Juveniles are found along the entire range, but a presumed nursery area is located in the Gulf of Maine

${ }^{1}$ Aasen, O. 1961. Some observations on the biology of the porbeagle shark (Lamna nasus L.). ICES C.M. Document 1961/109, 7 p. (senior author, unpubl. data; J. Sulikowski, unpubl. data) and the location of a pupping ground has been reported to be in the Sargasso Sea (Campana et al., 2010b). Like most large elasmobranchs, the porbeagle is slow growing and long lived (over 25 years) and has a relatively late age at maturity ( 8 years for males and 13 years for females), traits that make this species vulnerable to overexploitation and population depletion by direct and indirect fisheries $(\mathrm{Na}$ tanson et al., 2002).

In the western North Atlantic Ocean, commercial fisheries that target porbeagles have existed since the 1960 s, but catches rapidly declined in the latter part of that decade (Aasen ${ }^{1}$; Aasen, 1963; Campana et al. ${ }^{2}$. In the $1990 \mathrm{~s}$, Canadian fisher-

2 Campana, S., L. Marks, W. Joyce, and S. Harley. 2001. Analytical assessment of the porbeagle shark (Lamna nasus) population in the Northwest Atlantic, with estimates of long-term sustainable yield. Dep. Fish. Oceans, Can. Sci. Advis. Secr. Res. Doc. 2001/067, 17 p. [Available from website.] 


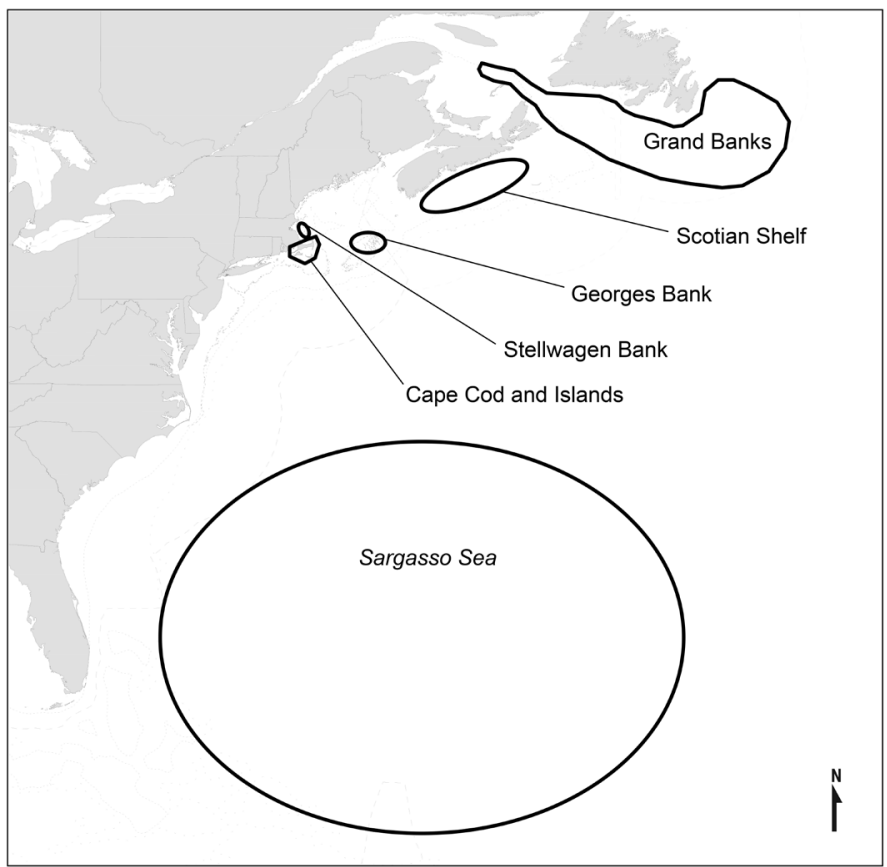

Figure 1

Map showing the areas used by female porbeagles (Lamna nasus) in different stages of maturity. The Grand Banks of Newfoundland and the Gulf of Saint Lawrence, Canada, form a reported mating area for porbeagles (Jensen et al., 2002). A portion of the Sargasso Sea has been identified as a pupping area (Campana et al., 2010b), and Stellwagen Bank is an area where females in a resting stage have been captured (this study). A portion of Georges Bank has been identified as a possible resting or mating area (Campana et al., 2010b; this study). Also shown are other locations where specimens were captured in this study. quires a large ovary with relatively high oocyte production and high ovulation rates (Gilmore et al., 2005). In the strictly oophagous species, such as the shortfin mako (Isurus oxyrinchus) and the common thresher shark (Alopias vulpinus), multiple embryos per uterus, long gestation periods, and long resting periods (the period between parturition and the next pregnancy) with 1 or 2 years between pregnancies is typical (Mollet et al., 2000; Gilmore et al., 2005; Natanson and Gervelis, 2013).

Jensen et al. (2002) conducted a study on the reproduction of the porbeagle in the western North Atlantic Ocean, assessing sharks taken by the U.S. and Canadian commercial fishing industries and scientific research surveys in the late 1990s. The sampling for that study took place from the Grand Banks of Newfoundland to the Scotian Shelf and into the Gulf of Maine. Jensen et al. (2002) demonstrated that the majority of mature females caught in the Grand Banks portion of the study area (87 of 88 porbeagles examined) were gravid after November. On the basis of the observation that all mature female porbeagles are pregnant in fall in these areas, Jensen et al. (2002) suggested that, contrary to the reproduction of most other lamnids, the reproductive cycle for the porbeagle is annual. In this paper, we report the previously undocumented presence of females in a resting stage of maturity. This discovery indicates that porbeagles exhibit a biennial reproductive cycle rather than an annual cycle in the western North Atlantic Ocean, substantially decreasing their resilience to direct and indirect fishing pressures. men began a limited fishery on porbeagles. In an attempt to avoid overfishing, the government of Canada imposed catch quotas for the commercial porbeagle fishery from 1995 into the early 2000s through the Canadian Atlantic Pelagic Shark Integrated Fisheries Management Plan (Campana et al. ${ }^{2}$ ). In 2013, the fishery for porbeagles was closed in Atlantic Canada (Campana et al. ${ }^{3}$ ). Similarly, in 2008, the National Marine Fisheries Service implemented Amendment 2 to the Consolidated Atlantic Highly Migratory Species Fishery Management Plan (NMFS, 2007), which significantly reduced landings of porbeagles by U.S. commercial fisheries (Curtis et al., 2016).

Reproduction of lamnid sharks is distinct from that of the majority of other elasmobranchs (Gilmore et al., 2005). One unifying characteristic for this group is oophagy, as a means of embryonic nutrition, which re-

\footnotetext{
${ }^{3}$ Campana, S. E., M. Fowler, D. Houlihan, W. Joyce, M. Showell, M. Simpson, C. Miri, and M. Eagles. 2015. Recovery Potential Assessment for Porbeagle (Lamna nasus) in Atlantic Canada. Dep. Fish. Oceans, Can. Sci. Advis. Secr. Res. Doc. 2015/041, 45 p. [Available from website.]
}

\section{Materials and methods}

Porbeagles were collected primarily from recreational fishermen at sportfishing tournaments held off Massachusetts and caught in the general vicinity of Stellwagen Bank or off Cape Cod ( $n=23$; Fig. 1). A small number of porbeagles were captured on pelagic longlines onboard a U.S. commercial fishing vessel off the Grand Banks of Newfoundland $(n=3)$. Sampling took place between 2004 and 2018. Additionally, data collected from porbeagle specimens captured between the Grand Banks of Newfoundland and Georges Bank prior to 2004, and used in Jensen et al. (2002), were reexamined.

Each shark was measured in fork length (FL), over the curve of the body from the tip of the nose to the fork of the tail, to the nearest millimeter and reported in centimeters. Whole weight was obtained when possible to the nearest pound and converted to kilograms.

A number of measurements and weights and information on conditions were taken from reproductive organs in female porbeagles to determine maturity stage. All specimens were measured fresh. Reproductive 


\section{Table 1}

Indices used to determine basic maturity in female porbeagles (Lamna nasus) based on data from Jensen et al. (2002) for female porbeagles caught between Georges Bank and the Grand Banks of Newfoundland, Canada, during 1979-1999. Adapted from Walker (2005b; table 4.1).

\begin{tabular}{|c|c|c|c|}
\hline Organ & Index & Description & Maturity classification \\
\hline Upper oviduct & $\begin{array}{l}\text { UO-1 } \\
\text { UO-2 } \\
\text { UO-3 }\end{array}$ & $\begin{array}{c}\leq 4.9 \mathrm{~mm} \\
>5 \text { to } \leq 7 \mathrm{~mm} \\
>7 \mathrm{~mm}\end{array}$ & $\begin{array}{l}\text { Immature } \\
\text { Uncertain } \\
\text { Mature }\end{array}$ \\
\hline Oviducal gland & $\begin{array}{l}\text { OG-1 } \\
\text { OG-2 } \\
\text { OG-3 }\end{array}$ & $\begin{array}{c}\leq 21 \mathrm{~mm} \\
>21 \text { to } \leq 24 \mathrm{~mm} \\
>24 \mathrm{~mm}\end{array}$ & $\begin{array}{l}\text { Immature } \\
\text { Uncertain } \\
\text { Mature }\end{array}$ \\
\hline Ovary length & $\begin{array}{l}\text { OL-1 } \\
\text { OL-2 } \\
\text { OL-3 }\end{array}$ & $\begin{array}{c}\leq 104 \mathrm{~mm} \\
>104 \text { to } \leq 121 \mathrm{~mm} \\
>121 \mathrm{~mm}\end{array}$ & $\begin{array}{l}\text { Immature } \\
\text { Uncertain } \\
\text { Mature }\end{array}$ \\
\hline Ovary width & $\begin{array}{l}\text { OW-1 } \\
\text { OW-2 } \\
\text { OW-3 }\end{array}$ & $\begin{array}{c}\leq 75.0 \mathrm{~mm} \\
>75.0 \text { to } \leq 86.6 \mathrm{~mm} \\
>86.6 \mathrm{~mm}\end{array}$ & $\begin{array}{l}\text { Immature } \\
\text { Uncertain } \\
\text { Mature }\end{array}$ \\
\hline Uterus length (total) & $\begin{array}{l}\text { UL-1 } \\
\text { UL-2 } \\
\text { UL-3 }\end{array}$ & $\begin{array}{c}\leq 343 \mathrm{~mm} \\
>343 \text { to } \leq 475 \mathrm{~mm} \\
>475 \mathrm{~mm}\end{array}$ & $\begin{array}{l}\text { Immature } \\
\text { Uncertain } \\
\text { Mature }\end{array}$ \\
\hline Uterus width & $\begin{array}{l}\text { UW-1 } \\
\text { UW-2 } \\
\text { UW-3 }\end{array}$ & $\begin{array}{c}\leq 26 \mathrm{~mm} \\
>26 \text { to } \leq 43 \mathrm{~mm} \\
>43 \mathrm{~mm}\end{array}$ & $\begin{array}{l}\text { Immature } \\
\text { Uncertain } \\
\text { Mature }\end{array}$ \\
\hline Membrane & & $\begin{array}{c}\text { Present } \\
\text { Absent }\end{array}$ & $\begin{array}{l}\text { Immature } \\
\text { Mature }\end{array}$ \\
\hline
\end{tabular}

tracts were measured on the right side of the specimen following Pratt (1979, 1993, 1996) and, specifically for the porbeagle, Jensen et al. (2002). Terminology follows Hamlett and Koob (1999) and Hamlett (1999), except where noted.

Reproductive organ measurements, taken to the nearest millimeter and at the widest part of the structure, included anterior oviduct width, oviducal gland width, ovary width and length, and uterus width and length. As per Jensen et al. (2002), 2 measurements were taken on the uterus: 1) from the anterior origin of the uterus to the vagina and 2) from the anterior origin of the uterus to the junction of the uteri (see fig. 1B in Jensen et al., 2002). Uterus width was taken midway along the anterior portion of the uterus (see fig. 1B in Jensen et al., 2002). For each ovary, oocytes were classified as mature if they contained yellow, vitellogenic material. The largest oocyte was measured in the field.

Males and females were classified as immature or mature, and mature females were further divided into 4 stages: ovulating, pregnant, postpartum, and resting. Using data from Jensen et al. (2002), we developed criteria for basic maturity classification (Table 1). Prior mating activity was assessed on the basis of the presence (immature) or absence (mature) of a vaginal mem- brane (hymen), and whether mating occurred recently was assessed on the basis of presence or absence of internal and external mating scars. The maturity stages of females were further determined by dissection: indications of past pregnancy included flaccid uteri (Pratt, 1979) and reduced ovaries with few mature or maturing oocytes. Individuals that appeared to have given birth in the current year were classified as postpartum, and those that had given birth but not recently were considered to be in a resting stage. A recently postpartum specimen was characterized by the presence of flocculent material consistent with portions of nutritive capsules along with milky uterine fluid (Gilmore et al., 2005); the uteri of a postpartum fish are very flaccid, and trophonemata are present (Natanson and Gervelis, 2013). Postpartum ovaries are generally large, hematose, and contain atretic oocytes.

Resting ovaries are often similar in appearance to the ovaries of almost mature juvenile sharks. It is, therefore, difficult to stage these fish by ovary condition alone, and other organ characteristics must be taken into account (Natanson and Gervelis, 2013). A late juvenile fish has a thin tubular uterus in contrast to the wider, slightly flaccid appearance of the resting uterus (previously expanded and then recovered) of adults. Additionally, a late-stage juvenile fish has a 


\section{Table 2}

Collection data for female porbeagles (Lamna nasus) caught between 2004 and 2018 off Massachusetts, in the general vicinity of Stellwagen Bank or off Cape Cod, and off the Grand Banks of Newfoundland, Canada. All organ measurements are presented in millimeters unless otherwise noted. A dash indicates that there were no data for a field. A single asterisk (*) indicates that the fish was abnormally thin, its organs were small for its length, and it was not used in analysis. Two asterisks (**) indicate that the fish was classified as postpartum. $\mathrm{T}=$ tournament; $\mathrm{CFV}=$ commercial fishing vessel; $\mathrm{RFV}=\mathrm{recreational}$ fishing vessel.

\begin{tabular}{|c|c|c|c|c|c|c|c|c|c|c|c|c|c|c|}
\hline $\begin{array}{l}\text { Maturity } \\
\text { status }\end{array}$ & $\begin{array}{c}\text { Date } \\
\text { captured }\end{array}$ & Source & $\begin{array}{c}\text { Fork } \\
\text { length } \\
(\mathrm{cm})\end{array}$ & $\begin{array}{l}\text { Weight } \\
(\mathrm{kg})\end{array}$ & $\begin{array}{l}\text { Upper } \\
\text { oviduct } \\
\text { width }\end{array}$ & $\begin{array}{l}\text { Oviducal } \\
\text { gland } \\
\text { width }\end{array}$ & $\begin{array}{l}\text { Uterus } \\
\text { width }\end{array}$ & $\begin{array}{l}\text { Uterus } \\
\text { length } \\
\text { (upper) }\end{array}$ & $\begin{array}{l}\text { Uterus } \\
\text { length } \\
\text { (total) }\end{array}$ & $\begin{array}{l}\text { Ovary } \\
\text { width }\end{array}$ & $\begin{array}{l}\text { Ovary } \\
\text { length }\end{array}$ & $\begin{array}{c}\text { Maximum } \\
\text { yolked egg } \\
\text { diameter }\end{array}$ & Membrane & $\begin{array}{l}\text { Ovary } \\
\text { weight } \\
\text { (g) }\end{array}$ \\
\hline \multirow[t]{7}{*}{ Juvenile } & $7 / 15 / 2017$ & $\mathrm{~T}$ & 202.0 & 120.2 & 4.8 & 6.5 & 8.3 & 190 & 260 & 42.3 & 71.7 & none & Present & 99 \\
\hline & $7 / 15 / 2016$ & $\mathrm{~T}$ & 204.1 & 104.3 & 3.2 & 5.3 & 8.3 & 235 & Unk & 55.3 & 53.5 & none & Present & 73 \\
\hline & $9 / 8 / 2016$ & CFV & 215.7 & - & 8.6 & 23.1 & 46.3 & 270 & 520 & 130.0 & 180.0 & 4.0 & Present & 264 \\
\hline & $7 / 16 / 2016$ & $\mathrm{~T}$ & 218.2 & 173.7 & 6.5 & 7.6 & 30.4 & 170 & 325 & 100.5 & 107.2 & 4.7 & Present & 158 \\
\hline & $7 / 20 / 2013$ & $\mathrm{~T}$ & 219.4 & 141.5 & - & - & - & - & - & - & - & - & - & - \\
\hline & $7 / 20 / 2013$ & $\mathrm{~T}$ & 221.4 & 142.0 & 6.5 & 19.5 & 19.8 & - & 430 & 85.0 & 135.0 & none & Present & - \\
\hline & 7/13/2018* & $\mathrm{T}$ & 234.7 & 151.0 & 4.2 & 5.2 & 10.0 & 210 & 320 & 73.3 & 87.2 & none & Present & 98 \\
\hline \multirow[t]{18}{*}{ Adult } & $7 / 13 / 2018$ & $\mathrm{~T}$ & 215.3 & 152.9 & 9.0 & 23.2 & 35.5 & 235 & 435 & 120.0 & 150.0 & none & Absent & 204 \\
\hline & $7 / 18 / 2008$ & $\mathrm{~T}$ & 217.5 & 150.6 & 12.3 & 24.5 & 41.4 & Unk & 460 & 109.0 & 158.0 & 3.0 & Absent & - \\
\hline & $7 / 22 / 2006$ & $\mathrm{~T}$ & 221.0 & 146.5 & 8.3 & 25.0 & 53.8 & 240 & 440 & 130.0 & 160.0 & 3.1 & Absent & 340 \\
\hline & $7 / 25 / 2009$ & $\mathrm{~T}$ & 223.0 & 163.7 & 9.5 & 28.9 & 49.7 & 210 & 440 & 128.0 & 180.0 & 3.0 & Absent & 463 \\
\hline & $7 / 18 / 2015$ & $\mathrm{~T}$ & 224.4 & 160.6 & 9.0 & 20.9 & 35.9 & 190 & 440 & 115.0 & 160.0 & none & Absent & - \\
\hline & $7 / 14 / 2017$ & $\mathrm{~T}$ & 227.0 & 152.4 & 8.3 & 18.8 & 26.4 & 240 & 470 & 160.0 & 158.0 & none & Absent & 335 \\
\hline & $7 / 16 / 2005$ & $\mathrm{~T}$ & 231.0 & 171.5 & 7.0 & 20.9 & 59.5 & 310 & 550 & 165.0 & 210.0 & 3.5 & Absent & 545 \\
\hline & $8 / 20 / 2011$ & $\mathrm{~T}$ & 233.0 & 181.4 & 9.6 & 24.3 & 64.4 & 350 & 500 & 120.0 & 180.0 & 3.5 & Absent & 319 \\
\hline & $7 / 20 / 2013$ & $\mathrm{~T}$ & 234.2 & 177.4 & 6.0 & 22.2 & 58.8 & - & 471 & 140.0 & 160.0 & none & Absent & - \\
\hline & $7 / 14 / 2017$ & $\mathrm{~T}$ & 237.7 & 181.0 & 8.4 & 28.7 & 53.8 & 270 & 512 & 150.0 & 150.0 & none & Absent & 321 \\
\hline & $7 / 15 / 2005$ & $\mathrm{~T}$ & 238.0 & 171.5 & 11.3 & 24.4 & 75.8 & 290 & 470 & 150.0 & 210.0 & 3.2 & Absent & 448 \\
\hline & $7 / 17 / 2004$ & $\mathrm{~T}$ & 239.0 & 181.4 & 7.6 & 27.7 & 62.9 & 250 & 320 & 132 & 195 & 3.3 & Absent & 445 \\
\hline & $7 / 22 / 2011$ & $\mathrm{~T}$ & 241.0 & 224.5 & 14.5 & 22.4 & 115.0 & 290 & 530 & 145.0 & 180.0 & none & Absent & 668 \\
\hline & $7 / 17 / 2015$ & $\mathrm{~T}$ & 241.0 & 196.0 & 8.3 & 18.6 & 74.2 & 250 & 485 & 143.0 & 225.0 & none & Absent & 700 \\
\hline & $9 / 20 / 2016$ & $\mathrm{CFV}$ & 244.2 & & 11.7 & 19.0 & 70.4 & 330 & 569 & 150.0 & 160.0 & $<1$ & Absent & 394 \\
\hline & $7 / 20 / 2012$ & $\mathrm{~T}$ & 247.0 & 199.6 & 7.3 & 23.7 & 60.8 & 270 & 515 & 110.0 & 190.0 & 5.2 & Absent & 328 \\
\hline & $9 / 7 / 2012^{* *}$ & $\mathrm{~T}$ & 247.6 & 272.5 & 7.4 & 32.3 & 140.0 & 355 & - & 165.0 & 252.0 & 4.0 & - & - \\
\hline & $9 / 20 / 2015$ & RFV & 248.0 & 219.1 & 9.6 & 32.5 & 100.3 & 390 & 575 & 130.0 & 200.0 & 4.0 & - & 650 \\
\hline
\end{tabular}

vaginal membrane, an indication that it had not previously mated (mature virgin stage; Jensen et al., 2002), and a resting female has had prior mating experience and no vaginal membrane. A resting fish, as opposed to a recently postpartum fish, has recovered uteri, and its ovary no longer contains atretic oocytes; nor is its ovary hematose. The resting ovary has small, mostly non-yolked oocytes and is ready for vitellogenesis. In our study, maturity status of both sexes was assigned to each shark, at the time of dissection, on the basis of all previously described reproductive organ characteristics and was verified by comparison with measurements taken by Jensen et al. (2002) (Table 1; Suppl. Figs. 1-3).

Data from Jensen et al. (2002) were reevaluated to determine whether resting females had been classified as adult without distinguishing the specific condition or maturity stage (i.e., resting versus pregnant). To attempt to determine stage, reproductive organ measurements from adult females not classified as either pregnant or ovulating were compared with those ob- tained from known resting females. Additionally, notes taken at the time of dissection were used in evaluating the specific adult stage. Because it was known that these fish were adults, the distinction between stages had to be made between resting and ready-to-mate females; therefore, the condition of the ovary, including maximum oocyte size, was the primary consideration. Only those fish for which their maturity stage could be firmly classified were used (i.e., specimens for which ovary data were not available were not reevaluated).

\section{Results}

Complete reproductive necropsies were conducted on 26 female porbeagles (202.0-248.0 cm FL), of which 7 fish were immature (202.0-234.7 cm FL). Of the remaining 19 mature individuals, 1 porbeagle $(247.6 \mathrm{~cm} \mathrm{FL})$ was postpartum and 18 individuals were in a resting stage (215.3-248.0 cm FL; Table 2). The resting females examined in this study had recovered uteri and ovaries 


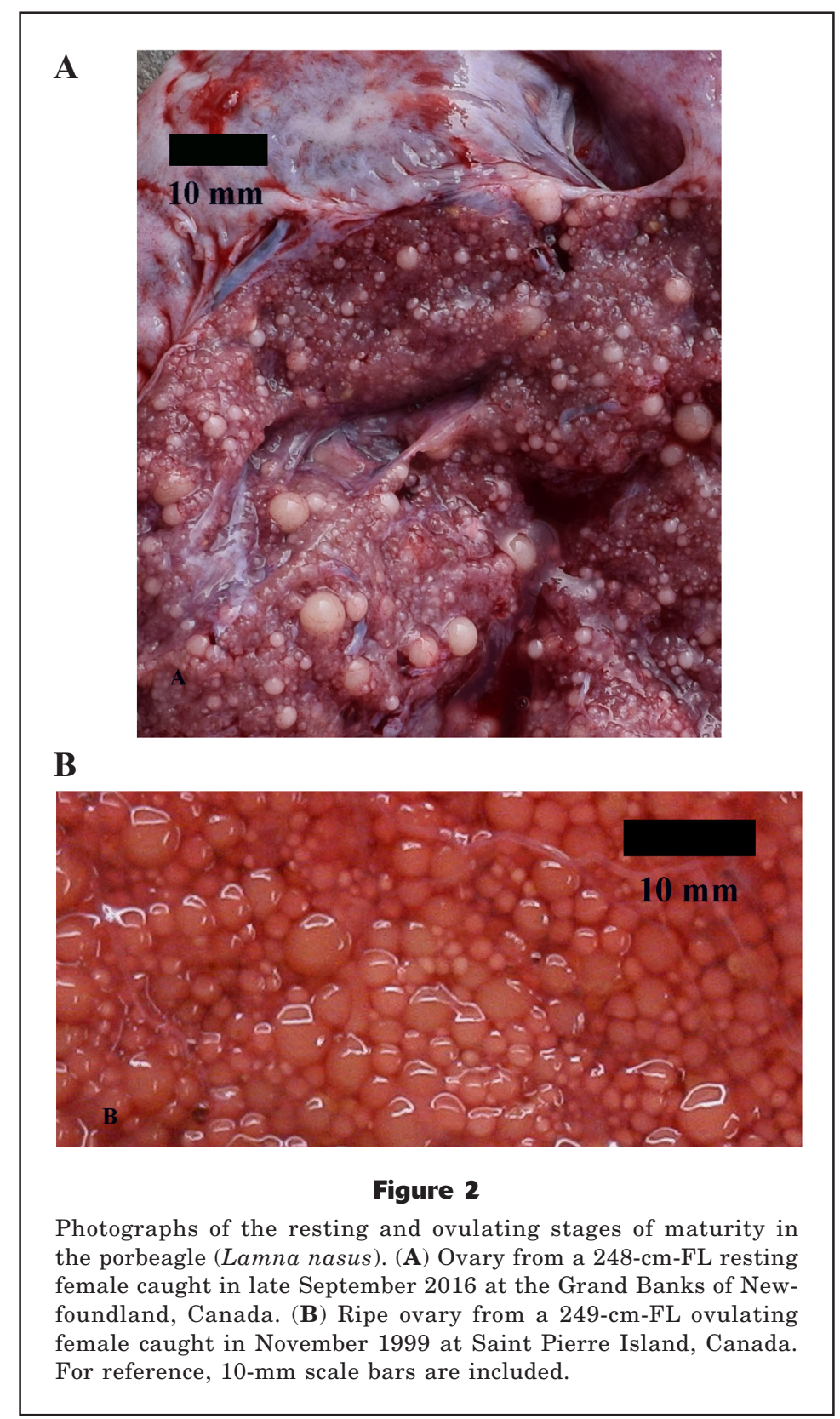

that had few small follicles (Fig. 2A), compared with a ripe ovary with many large oocytes (Fig. 2B). Fourteen females that were in the resting stage and caught on Stellwagen Bank were examined between July and September (Fig. 1). In addition, 2 sharks in the resting stage were caught east and south of Cape Cod, Nantucket, and Martha's Vineyard in July, and 2 sharks in the resting stage were taken on the Grand Banks of Newfoundland in September (Fig. 1). Three mature and 2 immature male porbeagles also were caught in the Gulf of Maine-Stellwagen Bank area during sampling for this study but will not be discussed.

Data from Jensen et al. (2002) for 20 adult females were reexamined by using the staging criteria from our study (Table 1). For 3 of these females, enough data were not available. Of the remaining 17 reexamined porbeagles, 2 females were postpartum, 1 fish was ready to ovulate, 9 individuals were ovulating, and 5 females were resting (Table 3 ). The 5 porbeagles in a resting stage were caught in July on Cultivator Shoals, located on Georges Bank $(n=1)$; in October on the Grand Banks of Newfoundland $(n=1)$; and in April on the Scotian Shelf east of La Have Bank $(n=3)$. This result indicates segregation of females in different maturity stages by time and location when compared with data from Jensen et al. (2002), who caught gravid and ovulating females primarily east of longitude $62^{\circ} \mathrm{W}$, particularly in the area of the Grand Banks of New- 


\section{Table 3}

Data from Jensen et al. (2002) reevaluated for this study for porbeagles (Lamna nasus) captured between 1989 and 1999 in the general vicinity of Georges Bank to off the Grand Banks of Newfoundland, Canada. All organ measurements are presented in millimeters unless otherwise noted. The vaginal membrane was absent in all of these specimens. A dash indicates that there were no data for a field.

\begin{tabular}{|c|c|c|c|c|c|c|c|c|c|c|c|}
\hline Maturity status & $\begin{array}{c}\text { Date } \\
\text { captured }\end{array}$ & $\begin{array}{l}\text { Fork } \\
\text { length } \\
(\mathrm{cm})\end{array}$ & $\begin{array}{l}\text { Weight } \\
(\mathrm{kg})\end{array}$ & $\begin{array}{c}\text { Upper } \\
\text { oviduct } \\
\text { width }\end{array}$ & $\begin{array}{l}\text { Oviducal } \\
\text { gland } \\
\text { width }\end{array}$ & $\begin{array}{l}\text { Uterus } \\
\text { width }\end{array}$ & $\begin{array}{l}\text { Uterus } \\
\text { length } \\
\text { (upper) }\end{array}$ & $\begin{array}{l}\text { Uterus } \\
\text { length } \\
\text { (total) }\end{array}$ & $\begin{array}{l}\text { Ovary } \\
\text { width }\end{array}$ & $\begin{array}{l}\text { Ovary } \\
\text { length }\end{array}$ & $\begin{array}{c}\text { Maximum } \\
\text { yolked egg } \\
\text { diameter }\end{array}$ \\
\hline \multirow[t]{5}{*}{ Resting } & 7/19/1989 & 240.0 & 172.4 & 10.0 & 27.0 & - & - & - & 75.0 & 195.0 & 2.5 \\
\hline & $4 / 2 / 1994$ & 220.0 & - & 8.0 & 25.0 & - & 320.0 & - & 120.0 & 155.0 & 2.0 \\
\hline & 4/6/1994 & 218.0 & - & 8.0 & 29.0 & - & 370.0 & - & 80.0 & 180.0 & 2.0 \\
\hline & $4 / 7 / 1994$ & 231.0 & - & - & 31.0 & - & 340.0 & - & 110.0 & 150.0 & 3.0 \\
\hline & 10/23/1993 & 244.0 & - & - & 28.0 & - & - & - & 110.0 & 150.0 & 1.0 \\
\hline Ready to ovulate & $11 / 26 / 1999$ & 217.0 & 128.0 & 11.3 & 37.2 & 37.5 & 160.0 & 450.0 & 135.0 & 175.0 & 6.0 \\
\hline \multirow[t]{9}{*}{ Ovulating } & $10 / 2 / 1999$ & 234.0 & 155.0 & 9.0 & 30.0 & 42.0 & 184.0 & 435.0 & 139.0 & 153.0 & 4.0 \\
\hline & 9/28/1999 & 228.5 & - & 5.0 & 28.0 & 39.0 & 235.0 & 535.0 & 126.0 & 177.0 & 6.0 \\
\hline & $5 / 20 / 1999$ & 230.5 & 118.5 & 6.0 & 21.0 & 48.0 & 235.0 & 514.0 & 122.0 & 169.0 & 3.0 \\
\hline & 10/11/1999 & 221.0 & - & 9.0 & 35.0 & 36.0 & 205.0 & 470.0 & 180.0 & 193.0 & 6.0 \\
\hline & $5 / 18 / 1999$ & 240.0 & 144.0 & 6.0 & 24.0 & 54.0 & 228.0 & 514.0 & 111.0 & 148.0 & - \\
\hline & $10 / 2 / 1999$ & 248.0 & & 8.0 & 35.0 & 30.0 & 160.0 & 515.0 & 142.0 & 181.0 & 4.0 \\
\hline & $5 / 18 / 1999$ & 229.5 & 135.0 & 9.0 & 23.0 & 39.0 & 292.0 & 605.0 & 112.0 & 136.0 & 4.0 \\
\hline & 6/1/1999 & 228.0 & 118.5 & 8.0 & 21.0 & 51.0 & 236.0 & 615.0 & 134.0 & 169.0 & 5.0 \\
\hline & 5/6/1999 & 241.0 & - & & 26.5 & 65.0 & 465.0 & 820.0 & 135.0 & 230.0 & 4.0 \\
\hline \multirow[t]{2}{*}{ Postpartum } & 5/5/1999 & 230.0 & 132.0 & 8.0 & 24.0 & 54.0 & 336.0 & 568.0 & 147.0 & 165.0 & 4.2 \\
\hline & $5 / 6 / 1997$ & 221.2 & - & 8.7 & 26.9 & - & 530.0 & - & 140.0 & 170.0 & - \\
\hline \multirow{3}{*}{$\begin{array}{l}\text { Unable to be } \\
\text { determined }\end{array}$} & 6/2/1999 & 216.0 & - & - & 21.0 & - & - & - & 130.0 & 152.0 & - \\
\hline & $5 / 6 / 1999$ & 233.0 & 145.0 & 7.0 & 21.5 & 38.5 & 296.0 & 580.0 & 114.0 & 130.0 & - \\
\hline & 4/8/1999 & 214.0 & - & 7.5 & 21.5 & 26.0 & 182.0 & 343.0 & & 104.0 & - \\
\hline
\end{tabular}

foundland and the mouth of the Saint Lawrence River (Fig. 2; Jensen et al., 2002).

\section{Discussion}

An essential component for assessing and managing populations of sharks is determining each species' reproductive biology (e.g., when sexual maturity occurs, the timing of seasonal cycles, or gestation length) (Walker, 2005a, 2005b). However, variability in these important reproductive parameters has been shown to occur within species (e.g., Lombardi-Carlson et al., 2003; Sulikowski et al., 2007; Castro, 2009; Driggers and Hoffmayer, 2009), complicating the management process. Therefore, because of the importance of reproductive data as inputs in demographic and population models (Cortés, 2002), it is imperative to accurately describe the life history of a species throughout its range.

Castro (2009) describes the complexities of the typical biennial reproductive cycle of the sand tiger (Carcharias taurus), a lamnid species that inhabits subtropical and temperate waters worldwide. It has been suggested that this species has a biennial cycle with consecutive vitellogenesis and gestation and with discontinuous ovulation in specimens captured in waters of Australia and the southwest Atlantic Ocean (Luci- fora et al., 2002; Bansemer, 2009). However, in North America, information on reproductive cycle is inconclusive, and an annual instead of biennial cycle has been reported (Castro, 2009). Indeed, only annual reproduction may be considered because of the inability of researchers to find the resting segment of the population of sand tigers that may be highly localized and unsampled to date (Castro, 2009). The existence of a previously unsampled resting portion of the population of porbeagles is indicated by the results of our study.

As in other lamnid species, at some point during gestation, the ovaries of a female porbeagle become exhausted; by the time of parturition, an ovary is depleted and hematose and contains atretic oocytes. A depleted ovary must then recover to a condition ready for vitellogenesis (Fig. 2A). Because it has been suggested that birth occurs between April and June and that mating occurs in the fall, an ovary of a porbeagle is unlikely to recover enough to ovulate and sustain a new brood by September (Fig 2; Jensen et al., 2002; Castro, 2009). In addition, sampling for our study took place by recreational fishermen between July and September in an area (primary area: Stellwagen Bank) geographically distinct from the primary sampling area of Jensen et al. (2002) in waters between Nova Scotia and the Grand Banks of Newfoundland (Fig. 1). Therefore, the observation of females in a resting phase ap- 
pears to represent a portion of the population that had remained unsampled until now.

Jensen et al. (2002) sampled porbeagles caught in commercial fisheries in an area of high abundance of porbeagles. They found that mature females in this area were either pregnant or ovulating, leading them to the conclusions that 1 ) this area is a mating ground and 2) porbeagles have annual reproduction. Further, the seasonality of spermatophore production, observations of females with fresh mating scars, and observations of males and females captured on the same longline indicate that porbeagles mate in the fall, primarily between September and November on the Grand Banks of Newfoundland and the vicinity (Jensen et al., 2002). Jensen et al. (2002) also predicted a gestation period of 8-9 months and pupping from April through June. According to Jensen et al. (2002), mature females would be recently postpartum in July and recovering to the point of mating (oocytes with diameters of $\sim 3-6 \mathrm{~mm}$ ) by September. However, this timing appears unrealistic for the samples collected in our study, on the basis of the condition of the resting ovaries observed in the summer (Fig. 2A). In addition, this study observed only one recently postpartum individual (caught in September), and the remainder of the individuals were recovered to the point where vitellogenesis had commenced. Therefore, on the basis of other lamnid studies and the known timing of porbeagle mating, oogenesis would require a year before they would be in mating condition, further indication that this shark has a biennial rather than an annual reproductive cycle.

An additional mating ground on Georges Bank has been indicated by the presence of "high catch rates of mature females, which did not appear to be feeding" in June 2007, observed by Campana et al. (2010a), although no detailed necropsy data were presented. However, because no males were captured with this group of females and the data of Jensen et al. (2002) indicates a fall mating season, it is unlikely that a mating aggregation occurs on Georges Bank in summer. On the basis of the findings of our study, we suggest that this aggregation was more consistent with resting than mating, particularly in light of the fact that Georges Bank is in geographic proximity to Stellwagen Bank (Fig. 1). Further, females assumed to be mature on the basis of size and tagged on Georges Bank, primarily in July 2008, have been shown to migrate to the Sargasso Sea. This migration was assumed to be for pupping (Campana et al., 2010b). On the basis of time of year, it is unlikely that these sharks were pregnant and would have had to travel to the mating area before pupping in the Sargasso Sea. The tracks of tagging data presented by Campana et al. (2010b; fig. 1) indicate that the sharks in that study did not travel to known mating grounds and were only assumed to be pregnant (no direct reproductive assessments were made). In light of the evidence from our study, for a resting area in Stellwagen Bank, and data from the Campana et al. (2010b) tagging study that indicate that porbeagles did not travel east of longitude $62^{\circ} \mathrm{W}$ but resided in the areas of the Gulf of Maine, Stellwagen Bank, and Georges Bank, it is possible that the females tagged by Campana et al. (2010b) were in a resting stage and transited to the Sargasso Sea for unknown reasons, possibly related to feeding.

The discovery of a resting portion of the population of porbeagles in the western North Atlantic Ocean has important implications for fisheries management. The inclusion of a resting period in the reproductive cycle of the porbeagle means at least some portion of the female population is not reproducing annually. A decrease in productivity on the basis of non-annual reproduction needs to be considered because such a decrease would reduce the resilience of this species to direct and indirect fishing pressures. Continued research on the migrations and distribution of porbeagles by their adult maturity stage is necessary to provide effective management for this species.

\section{Acknowledgments}

We thank the various shark tournament officials and fishermen for allowing us access to their catch. We also thank the captain and crew of the F/V Eagle Eye II for allowing us to sail onboard and sample catch and $\mathrm{C}$. McCandless for making maps.

\section{Literature cited}

Aasen, O.

1963. Length and growth of the porbeagle (Lamna nasus, Bonnaterre) in the North West Atlantic. Fisk.dir. Skr., Havund. 13:20-37.

Bansemer, C. S.

2009. Population biology, distribution, movement patterns and conservation requirements of the grey nurse shark (Carcharias taurus Rafinesque, 1810) along the east coast of Australia. Ph.D. diss., 159 p. Univ. Queensland, Brisbane, Australia.

Campana, S., W. Joyce, L. Marks, P. Hurley, L. J. Natanson, N. E. Kohler, C. F. Jensen, J. J. Mello, H. L. Pratt Jr., S. Myklevoll, et al.

2008. The rise and fall (again) of the porbeagle shark population in the Northwest Atlantic. In Sharks of the open ocean: biology, fisheries and conservation (M. D. Camhi, E. K. Pikitch, and E. A. Babcock, eds.), p. 445461. Blackwell Publishing, Ltd., Oxford, UK.

Campana, S. E., A. J. F. Gibson, M. Fowler, A. Dorey, and W. Joyce.

2010a. Population dynamics of porbeagle in the Northwest Atlantic, with an assessment of status to 2009 and projections for recovery. Collect. Vol. Sci. Pap. ICCAT 65(6):2109-2182.

Campana, S. E., W. Joyce, and M. Fowler.

2010b. Subtropical pupping ground for a cold-water shark. Can. J. Fish. Aquat. Sci. 67:769-773. Crossref

Castro, J. I.

2009. Observations on the reproductive cycle of some viviparous North American sharks. Aqua Int. J. Ichthyol. 15:205-222. 
2011. The sharks of North America, 640 p. Oxford Univ. Press, Inc., New York.

Cortés, E.

2002. Incorporating uncertainty into demographic modeling: application to shark populations and their conservation. Conserv. Biol. 16:1048-1062. Crossref

Curtis, T. H., S. Laporte., E. Cortes, G. DuBeck, and C. McCandless.

2016. Status review report: porbeagle shark (Lamna nasus), 56 p. Final report to National Marine Fisheries Service, Office of Protected Resources. [Available from website.]

Driggers, W. B., III, and E. R. Hoffmayer.

2009. Variability in the reproductive cycle of finetooth sharks, Carcharhinus isodon, in the northern Gulf of Mexico. Copeia 2009:390-393. Crossref

Gilmore, R. G., Jr., O. Putz, and J. W. Dodrill.

2005. Oophagy, intrauterine cannibalism and reproductive strategy in lamnoid sharks. In Reproductive biology and phylogeny of Chondrichthyes: sharks, batoids, and chimaeras, vol. 3 (W. C. Hamlett, ed.), p. 435-462. Sci. Publishers, Enfield, NH.

Hamlett, W. C.

1999. Male reproductive system. In Sharks, skates and rays: the biology of elasmobranch fishes (W. C. Hamlett, ed.), p. 444-470. Johns Hopkins Univ. Press, Baltimore, MD.

Hamlett, W. C., and T. J. Koob.

1999. Female reproductive system. In Sharks, skates and rays: the biology of elasmobranch fishes (W. C. Hamlett, ed.), p. 398-443. Johns Hopkins Univ. Press, Baltimore, MD.

Jensen, C. F., L. J. Natanson, H. L. Pratt Jr., N. E. Kohler, and S. E. Campana.

2002. The reproductive biology of the porbeagle shark (Lamna nasus) in the western North Atlantic Ocean. Fish. Bull. 100:727-738.

Lombardi-Carlson, L. A., E. Cortés, G. R. Parsons, and C. A. Manire.

2003. Latitudinal variation in life-history traits of bonnethead sharks, Sphyrna tiburo, (Carcharhiniformes: Sphyrnidae) from the eastern Gulf of Mexico. Mar. Freshw. Res. 54:875-883. Crossref

Lucifora, L. O., R. C. Menni, and A. H. Escalante.

2002. Reproductive ecology and abundance of the sand tiger shark, Carcharias taurus, for the southwestern Atlantic. ICES J. Mar. Sci. 59:553-561. Crossref

Mollet, H. F., G. Cliff, H. L. Pratt Jr., and J. D. Stevens.

2000. Reproductive biology of the female shortfin mako, Isurus oxyrinchus Rafinesque, 1810, with comments on the embryonic development of lamnoids. Fish. Bull. 98:299-318.

Natanson, L. J., and B. J. Gervelis.

2013. The reproductive biology of the common thresher shark in the western North Atlantic Ocean. Trans. Am. Fish. Soc. 142:1546-1562. Crossref

Natanson, L. J., J. J. Mello, and S. E. Campana.

2002. Validated age and growth of the porbeagle shark, Lamna nasus, in the western North Atlantic Ocean. Fish. Bull. 100:266-278.

NMFS (National Marine Fisheries Service).

2007. Final amendment 2 to the consolidated Atlantic highly migratory species fishery management plan, 726 p. NOAA, Natl. Mar. Fish. Serv., Off. Sustainable Fish., Highly Migratory Species Manage. Div., Silver Spring, MD.

Pratt, H. L., Jr.

1979. Reproduction in the blue shark, Prionace glauca. Fish. Bull. 77:445-470.

1993. The storage of spermatozoa in the oviducal glands of western North Atlantic sharks. Environ. Biol. Fish. 38:139-149. Crossref

1996. Reproduction in the male white shark. In Great white sharks, the biology of Carcharodon carcharias (A. P. Klimley and D. G. Ainley, eds.), p. 131-138. Academic Press, San Diego, CA.

Sulikowski, J. A., W. B. Driggers III, T. S. Ford, R. K. Boonstra, and J. K. Carlson.

2007. Reproductive cycle of the blacknose shark Carcharhinus acronotus in the Gulf of Mexico. J. Fish Biol. 70:428-440. Crossref

Walker, T. I.

2005a. Management measures. In Management techniques for elasmobranch fisheries (J. A. Musick and R. Bonfil, eds.), p. 285-321. FAO Fish. Tech. Pap. 474. FAO, Rome.

2005b. Reproduction in fisheries science. In Reproductive biology and phylogeny of Chondrichthyes: sharks, batoids, and chimaeras, vol. 3 (W. C. Hamlett, ed.), p. 81-126. Sci. Publishers, Enfield, NH. 